\title{
A Basic Study on Unit Module Planning for the Design Diversity of Modular Architecture
}

\author{
Jiweon Kim11), Ri Ryu2), Yongseong $\mathrm{Kim}^{3}$ )
}

\begin{abstract}
The purpose of this study is to provide preliminary data for the revitalization and design diversity of modular architecture in the country through domestic and overseas cases. The unit modular system is a construction method in which architectural modules pre-manufactured at factories are installed on site, and this method is for reducing the construction period, securing the environmental friendliness and reusability, and minimizing environmental damages that occur at the time of construction. The structure type, modular architecture, economic feasibility, constructability and environmental friendliness were drawn by comparing and analyzing relevant cases actively carried out on housing facilities in various countries. Domestic cases show relatively low-rise, low economic feasibility and constructability in comparison to overseas cases, and domestic awareness, R\&D and revitalization of modular architecture are highly insufficient. Studies and developments regarding the hybrid system, alternatives for uniform and simple plane composition and the improvement of the performance of industrialization facilities are urgently needed in order to revitalize domestic modular architecture.
\end{abstract}

Keywords : Modular Construction, Modular Architecture, Unit Module, Environmental-Friendly, Design Diversity

\section{Introduction}

\subsection{Background and Purpose of Study}

Modular architecture refers to the construction method to transport single module units manufactured or produced at a factory in advance to a construction site and complete the building by simply assembling such module units. Modular architecture has various advantages,

Received(November 22, 2018), Review Result(1st: December 12, 2018, 2nd: January 22, 2019), Accepted(March 10, 2019)

1) (Master Course Student) 02702 Dept. of Architectural Design, Graduate School of Techno Design, Kookmin Univ, Jeongneung-dong, Seongbuk-gu, Seoul, Korea

email: dnjslj92@gmail.com

2) (Research Professor) 02702 Dept. of Architectural Design, Graduate School of Techno Design, Kookmin Univ, Jeongneung-dong, Seongbuk-gu, Seoul, Korea

email: ri23414@hanmail.net

3) (Professor, Corresponding Author) 02702 Dept. of Architectural Design, Graduate School of Techno Design, Kookmin Univ, Jeongneung-dong, Seongbuk-gu, Seoul, Korea

email: yongkim@kookmin.ac.kr 
including reduction of design costs, material costs and construction period, and is being applied to various high-rise buildings since recently. Studies regarding various module units including modular architecture housing, dormitories, hospitals and schools and architectural designing regarding its structure and forms are being carried out in foreign countries[1]. In the case of Korea, however, the development of module units in consideration of economical and environmental characteristics is insufficient due to difficulty regarding the diversity of forms from the standardized construction method and structure unlike various structures in foreign countries. The stack method can be considered as one of the methods to promote the diversity of modular architecture, but there has been only a small number of design and construction cases using this method in Korea; thus, it is difficult to apply this method.

Therefore, the purpose of this study is to present a unit module considering various stack methods as a measure for adding design diversity to modular architecture[2].

\subsection{Range and Method of Study}

In this study, the representative modular architecture for each country was limited to housing facilities and relevant types and structures were compared and analyzed. The reason that the range is set to only one type, which is housing facilities, is to compare similar domestic and overseas modular architecture types, and because it also has significance in the presentation of standardization for designing modular architecture for housing facilities. There is growing interest in and demand for modular housing facilities since the number of single-person households has increased, and various studies for the diversity of modular architecture are being carried out. This study is carried out in the following way.

1) The concept and features of modular construction are identified through theoretical studies and modular construction in residential facilities are defined.

2) Modular residential construction cases are investigated to identify the trends of modular construction.

3) Domestic and foreign cases are analyzed based on five features and the characteristics that must be taken into consideration for formative diversity of modular construction are identified.

4) Based on the analysis, a unit module that can act as the basics for various stacking methods and formative diversity is deduced. 


\section{Theoretical Considerations of Modular Architecture}

\subsection{Necessity of Modular Architecture}

Studies on the design of modular architecture in Korea present design plans, including housing facilities, military facilities and dormitory facilities. However, previous studies have been carried out according to the construction method for each function of modular architecture, so design diversity is insufficient. Also, previous studies indicate that modular architecture is insufficient in terms of competitiveness in comparison with informal structures, and design diversity can be secured if plane and elevation which are currently standardized, residential performance and joint detail are developed[3]. In domestic modular architecture studies conducted by Park \& Oh (2013) and Kim (2013), the necessity of study on design diversity is presented. In order to apply modular architecture to various buildings, including housing facilities, measures to improve its design diversity is necessary to apply various elements regarding environmentally friendly aesthetic elements of buildings[4].

Domestic modular architecture has been applied to buildings such as military barracks, so design diversity did not draw close attention. However, diversity of design is attempted using a method to add variety to the form of elevation such as the attachment of a metallic frame since unit modular construction has been applied to housing facilities, and such method may cause the problem of increasing the workload at the time of field construction, making the work more complicated or increasing costs. Therefore, modular architecture has limitations in terms of elevation variation strategy, and a new attempt for design diversity of domestic modular architecture is necessary[5].

\subsection{Concept and Characteristics of Modular Architecture}

The concept of module first appeared from Greek architecture with the purpose of producing parts at a factory in order to reduce the construction process and period. Modular architecture has been expanded into various concepts, including prefabricated architecture, industrialized architecture and unit modular architecture since the 1990s, and it is used as the term that refers to all buildings for which the production process and the assembly process are carried out in a separate space[6]. Modular architecture means architecture of a form in which various structural members (interior material, machine equipment, etc.) are produced and manufactured 
at a factory in advance, and such materials and machine equipment are delivered to the site and assembled on-site, unlike previous construction carried out on-site. Advantages of modular architecture include the fact that the installation of external facilities and construction can be carried out separately, and repair or maintenance can be carried out easily in case of a problem or a building owner's demands in the future[7].

Products manufactured at a factory and modular architecture are similar in that they are manufactured at a factory. Therefore, for modular architecture, quality can be improved, the costs and construction period can be reduced, and they can be disassembled and reused. In the case of schools and military facilities where various environmental changes such as an increase or a decrease in the number of people and the reorganization of structures may occur, modular architecture can be promptly and conveniently extended, removed, reconstructed and downsized, and the amount of waste material is also clearly reduced[8].

[Table 1] Characteristics of Modular Architecture[9]

\begin{tabular}{|c|c|}
\hline Short build times & $\begin{array}{l}\text { - The construction period is reduced by } 60 \% \text { in comparison with the } \\
\text { previous construction period. } \\
\text { - Since modules are manufactured at a factory and transported to a } \\
\text { construction site, foundation work and construction can be carried } \\
\text { out at the same time. }\end{array}$ \\
\hline Eco-friendliness & $\begin{array}{l}\text { - Modules used in modular architecture can be disassembled at the } \\
\text { time of downsizing or removing the building and they can be } \\
\text { recycled or reused in the future. }\end{array}$ \\
\hline Convenient upkeeping & $\begin{array}{l}\text { - Module parts can be replaced or repaired conveniently in the } \\
\text { future in case of destruction or deterioration. }\end{array}$ \\
\hline Productivity & $\begin{array}{l}\text { - Minimal materials are used through production at a factory. } \\
\text { - Repetitive production is possible. } \\
\text { - Standardized and large-quantity production are possible. }\end{array}$ \\
\hline Stability (Superior quality) & $\begin{array}{l}\text { - The factory production method ensures a low rate of defects and } \\
\text { constant quality. }\end{array}$ \\
\hline Light weight & $\begin{array}{l}\text { - Light weight steel frames that enable weight reduction are used. } \\
\text { (These steel frames account for approximately } 30 \% \text { of the building } \\
\text { load in comparison with previous masonry buildings.) }\end{array}$ \\
\hline Design flexibility & $\begin{array}{l}\text { - Various vertical and horizontal planes using steel structure } \\
\text { modules with excellent structural performance are possible. }\end{array}$ \\
\hline
\end{tabular}

\subsection{Types of Modular Construction}

The construction method and stacking type should also be considered for the design diversity of modular architecture.

The classifications and definitions of modular architecture stacking types are as follows. 
[Table 2] Stacking Types of Modular Construction

\begin{tabular}{|c|c|c|}
\hline Type & Continuous Stacking method \\
\hline Image & $\begin{array}{c}\text { A method to stack unit-modules } \\
\text { continuously in the horizontal-vertical } \\
\text { direction }\end{array}$ & $\begin{array}{c}\text { A method to cross-stack unit-modules at } \\
\text { the angles of } 0^{\circ} \text { and } 90^{\circ}\end{array}$ \\
\hline Definition & \begin{tabular}{c} 
ang method \\
\hline
\end{tabular}
\end{tabular}

Modular construction is divided into 3 methods, and the most popular method is the unit box which is the form for stacking box-type structural modules manufactured at a factory for construction. The basic structural frame, electricity and facility installation and internal and external finishing works are completed at a factory and the modules are delivered to a site, and only the stacking process is carried out on the site. Thus, the costs and time can be reduced significantly[6].

In modular architecture, the frame method and bearing wall method module are mainly used. Table 3 shows the characteristics of the bearing wall method and frame method modules.

[Table 3] Structure Type of Modular Architecture

\begin{tabular}{|l|l|l|}
\hline Type & Frame method & Bearing wall method \\
\hline Image & $\begin{array}{l}\text { The walls of the four sides are composed } \\
\text { by arranging steel studs or pipes at } \\
\text { intervals of } 300 \mathrm{~mm} \text { and } 600 \mathrm{~mm}\end{array}$ & $\begin{array}{l}\text { Beams and columns are constructed } \\
\text { through bolting or welding in } \\
\text { manufactured products. }\end{array}$ \\
\hline Composition \\
\hline Method & $\begin{array}{l}\text { The vertical load between unit modules } \\
\text { is delivered through the wall. }\end{array}$ & $\begin{array}{l}\text { The load is delivered through beams and } \\
\text { columns. }\end{array}$ \\
\hline Usage & $\begin{array}{l}\text { Schools, army barracks, housing and } \\
\text { commercial buildings, etc. }\end{array}$ & \begin{tabular}{l} 
Residential buildings in commercial areas \\
\hline
\end{tabular}
\end{tabular}

Panelizing is the method in which floor and wall panels, which are not box-shaped units, are manufactured at a factory and such panels are assembled on-site. The unit box is of the form that requires stacking such unit boxes to create a space, while in panelizing, walls that 
constitute a space are manufactured as modules. In comparison to the unit box, there are no restrictions in transporting modules and it is flexible for plane composition. However, modules should be assembled on-site, so the construction period reduction rate is lower than other modular architecture methods[7].

In-fill is the method of modular construction in which the framework is piled up using steel frames and steel-reinforced concrete frames on-site and non-bearing units manufactured in box form are inserted inside such framework. It is similar to the method for manufacturing and inserting a drawer into a chest of drawers[8].

\section{Consideration of Design Diversity through Analyzing Cases of Domestic and Overseas Modular Architecture}

\subsection{Analysis Method for Modular Architecture}

Cases selected for investigation were domestic and overseas residential facilities. The cases were divided into five categories according to their advantages and required performance of modular architecture for case analysis.

[Table 4] Requirements of Modular Architecture Plan[9]

\begin{tabular}{|c|c|c|}
\hline $\begin{array}{c}\text { Classific } \\
\text { ation }\end{array}$ & Type of Analysis & Analysis Contents \\
\hline \multirow{4}{*}{$\begin{array}{c}\text { Planning } \\
\text { characte } \\
\text { ristics }\end{array}$} & Usability & $\begin{array}{c}\text { Insulation, sound insulation, soundproof performance, space } \\
\text { zoning }\end{array}$ \\
\cline { 2 - 3 } & $\begin{array}{c}\text { Environmental } \\
\text { friendliness }\end{array}$ & $\begin{array}{c}\text { Quality management, additional module installation, expansion } \\
\text { and cancellation, variability }\end{array}$ \\
\cline { 2 - 3 } & Economic feasibility & $\begin{array}{c}\text { Large-volume production, reduction of labor costs, material costs } \\
\text { and construction period, and standardization }\end{array}$ \\
\cline { 2 - 3 } & Design & Exterior design, building identity and characteristics \\
\hline
\end{tabular}

3.2 Domestic and Overseas Modular Architecture Cases, Summary of Architecture and Analysis of Required Performance

In Korea, the type of modular architecture is mostly military facilities, and residential facilities have been appearing since the 2000s. In foreign countries, modular architecture is used in various types and structures such as apartment houses, dormitories, mixed-use buildings, offices 
and schools. In overseas cases, most modular buildings are low-rise buildings, and efforts and R\&D for addressing instability and structural problems that appear in high-rise modular buildings are being carried out continuously[10][11].

Overseas cases show that the development and studies of high-rise module unit buildings are undertaken rapidly in the U.S. and U.K. and the systems and structures are developed and constructed in accordance with the characteristics of each country.

[Table 5] Overview of Overseas Modular Architecture

\begin{tabular}{|c|c|c|c|c|c|}
\hline \multirow[b]{2}{*}{$\begin{array}{l}\text { Classifica } \\
\text { tion }\end{array}$} & \multicolumn{5}{|c|}{ Domestic Cases } \\
\hline & $\begin{array}{c}\text { MUTO } \\
\text { Cheongdam }\end{array}$ & $\begin{array}{l}\text { Rental housing } \\
\text { in } \\
\text { Seodaemun-gu }\end{array}$ & $\begin{array}{l}\text { Mini House in } \\
\text { Guro-dong }\end{array}$ & $\begin{array}{c}\text { Public } \\
\text { dormitory in } \\
\text { Gongneung-dong }\end{array}$ & Staco \\
\hline Image & & & & & \\
\hline $\begin{array}{l}\text { Number } \\
\text { of floors }\end{array}$ & $\begin{array}{l}\text { Low-rise type } \\
\text { (4 floors) }\end{array}$ & $\begin{array}{c}1 \text { basement } \\
\text { level, } 4 \text { stories } \\
\text { above ground }\end{array}$ & $\begin{array}{l}2 \text { stories above } \\
\text { ground } \\
\text { (including semi } \\
\text { basement) }\end{array}$ & $\begin{array}{l}\text { Low-rise type } \\
\text { (4 floors) }\end{array}$ & High-rise type \\
\hline Usage & Rental housing & Rental housing & $\begin{array}{l}\text { Detached } \\
\text { housing }\end{array}$ & Rental housing & Officetel \\
\hline $\begin{array}{l}\text { Unit } \\
\text { module }\end{array}$ & $\begin{array}{l}3.3(\mathrm{w}) \times 6.6(\mathrm{~d}) \times 3 . \\
0(\mathrm{~h}) \text { basic type }\end{array}$ & $\begin{array}{c}3.2(\mathrm{w}) \times 6.25(\mathrm{~d}) \times 2 \\
8(\mathrm{~h}) \\
3.2(\mathrm{w}) \times 4.8(\mathrm{~d}) \times 2.8 \\
(\mathrm{~h})\end{array}$ & $2.9 \times 4.8 \times \mathrm{VAR}$ & $\begin{array}{c}2.33(\mathrm{w}) \times 5.2(\mathrm{~d}) \times 3 . \\
05(\mathrm{~h})\end{array}$ & $\begin{array}{l}2.7(\mathrm{w}) \times 6.6(\mathrm{~d}) \times 3 . \\
0(\mathrm{~h}) \text { basic type }\end{array}$ \\
\hline $\begin{array}{l}\text { Module } \\
\text { image }\end{array}$ & & & $\begin{array}{l}\text { 모 }= \\
\square= \\
\square=\end{array}$ & {$\left[\begin{array}{ll}7 \\
-1\end{array}\right.$} & {$\left[\begin{array}{l}10 \\
0 \\
0\end{array}\right.$} \\
\hline $\begin{array}{l}\text { Construct } \\
\text { ion } \\
\text { method }\end{array}$ & $\begin{array}{l}\text { Low-rise type } \\
\text { stacking } \\
\text { method }\end{array}$ & $\begin{array}{l}\text { Less than } 4 \\
\text { stories } \\
\text { continuous } \\
\text { stacking } \\
\text { method }\end{array}$ & $\begin{array}{l}2 \text { stories } \\
\text { continuous } \\
\text { stacking } \\
\text { method }\end{array}$ & $\begin{array}{l}\text { RC structure } \\
\text { for the 1st } \\
\text { floor, modular } \\
\text { structure for } \\
\text { the second to } \\
\text { fourth floors }\end{array}$ & $\begin{array}{l}\text { Nonbearing } \\
\text { wall/steel } \\
\text { structure } \\
\text { module } \\
\text { frame method }\end{array}$ \\
\hline $\begin{array}{l}\text { Type of } \\
\text { structural } \\
\text { system } \\
\text { in unit } \\
\text { module }\end{array}$ & $\begin{array}{c}\text { Nonbearing } \\
\text { wall/steel } \\
\text { frame structure } \\
\text { Frame method }\end{array}$ & $\begin{array}{l}\text { Steel frame } \\
\text { structure }\end{array}$ & $\begin{array}{l}\text { Steel frame } \\
\text { structure }\end{array}$ & $\begin{array}{l}\text { Steel frame } \\
\text { structure }\end{array}$ & $\begin{array}{l}\text { Constructed } \\
\text { using the in-fill } \\
\text { method for } \\
\text { each slab } \\
\text { structure, } \\
\text { high-rise type }\end{array}$ \\
\hline
\end{tabular}


[Table 6] Overview of Domestic Modular Architecture[12-19]

\begin{tabular}{|c|c|c|c|c|c|}
\hline \multirow[b]{2}{*}{ Classification } & \multicolumn{5}{|c|}{ Overseas Cases } \\
\hline & Murray Grove & $\begin{array}{c}\text { SEKISUI Heim } \\
\text { modular house } \\
\text { in Japan }\end{array}$ & Space Box & $\begin{array}{c}\text { Carmel Place } \\
\text { (My Micro NY) }\end{array}$ & Caledonian \\
\hline \multicolumn{6}{|l|}{ Image } \\
\hline $\begin{array}{l}\text { Number of } \\
\text { floors }\end{array}$ & $\begin{array}{c}5 \text { floors above } \\
\text { ground }\end{array}$ & $\begin{array}{l}\text { Low-rise type } \\
\text { (3 floors) }\end{array}$ & $\begin{array}{l}\text { Low-rise type, } \\
3 \text { floors }\end{array}$ & 10 floors & $\begin{array}{c}\text { Consists of } 4 \\
\text { floors, } 8 \text { floors, } \\
11 \text { floors and } \\
17 \text { floors }\end{array}$ \\
\hline Usage & $\begin{array}{c}\text { Apartment } \\
\text { housing }\end{array}$ & Housing & Dormitory & $\begin{array}{c}\text { Apartment } \\
\text { houses }\end{array}$ & Rental housing \\
\hline Unit module & $3.2 \times 8.0 \times 3.0$ & $3.6(\mathrm{w}) \times 8.55(\mathrm{~d})$ & $\begin{array}{c}3.5(\mathrm{w}) \times 7.5(\mathrm{~d}) \times 2 \\
.8(\mathrm{~h}) \text { basic } \\
\text { type (Use } \\
\text { in-company } \\
\text { standards) }\end{array}$ & $\begin{array}{c}12.5 \mathrm{~m} \times 30 \mathrm{~m} \\
23 \sim 34 \mathrm{~m}^{2}\end{array}$ & $\begin{array}{l}4.2(\mathrm{w}) \times 18(\mathrm{~d}) \times 4.1 \\
\text { (h) maximum } \\
\text { standards }\end{array}$ \\
\hline \multicolumn{6}{|l|}{$\begin{array}{l}\text { Image of } \\
\text { module }\end{array}$} \\
\hline $\begin{array}{l}\text { Construction } \\
\text { method }\end{array}$ & $\begin{array}{l}\text { Continuous } \\
\text { stacking } \\
\text { method }\end{array}$ & $\begin{array}{l}\text { Less than } 3 \\
\text { stories } \\
\text { continuous } \\
\text { stacking } \\
\text { method }\end{array}$ & $\begin{array}{l}\text { Construction } \\
\text { using stacking } \\
\text { method, } \\
\text { low-rise type }\end{array}$ & Stacking method & $\begin{array}{l}\text { Less than } 11 \\
\text { stories stacking } \\
\text { method, } \\
\text { bracing } \\
\text { reinforcement } \\
\text { work (core } \\
\text { structure) }\end{array}$ \\
\hline $\begin{array}{c}\text { Type of } \\
\text { structural } \\
\text { system in } \\
\text { unit module }\end{array}$ & $\begin{array}{l}\text { Steel frame } \\
\text { structure }\end{array}$ & Frame structure & $\begin{array}{c}\text { Integrated } \\
\text { bearing wall } \\
\text { method }\end{array}$ & $\begin{array}{l}\text { Self-supporting } \\
\text { steel frame } \\
\text { module }\end{array}$ & $\begin{array}{l}\text { Integrated } \\
\text { bearing wall } \\
\text { method }\end{array}$ \\
\hline
\end{tabular}

Facilities selected for the cases were compared and analyzed according to the presented analysis framework as shown in Table 3, and three evaluation indicators (0: high, $\mathbf{0}$ : average, $\bigcirc$ : low) were presented based on usability, constructability, environmental friendliness, economic feasibility and design. 
By analyzing the five fields, this study aims at proposing plans for formative diversity considering the characteristics that can be complementary among various characteristics.

Features drawn through comparative analysis of domestic and foreign cases are shown in the five cases for module construction characteristics, but it was found to be high in usability and environment-friendliness, while being relatively low for economic feasibility and design. Furthermore, it showed that domestic cases were judged to be relatively lower than foreign cases.

[Table 7] Required Performance of Modular Architecture Through Cases

\begin{tabular}{|c|c|c|c|c|c|c|c|c|c|c|}
\hline nation & \multicolumn{5}{|c|}{ Domestic } & \multicolumn{5}{|c|}{ Overseas } \\
\hline $\begin{array}{l}\text { Classifi } \\
\text { cation }\end{array}$ & $\begin{array}{l}\text { MUTO } \\
\text { Cheon } \\
\text { gdam }\end{array}$ & $\begin{array}{c}\text { Rental } \\
\text { housing } \\
\text { in } \\
\text { Seodae } \\
\text { mun-gu }\end{array}$ & $\begin{array}{c}\text { Mini } \\
\text { house } \\
\text { in } \\
\text { Guro- } \\
\text { dong }\end{array}$ & $\begin{array}{c}\text { Public } \\
\text { dormitory } \\
\text { in } \\
\text { Gongneu } \\
\text { ng-dong }\end{array}$ & $\begin{array}{l}\text { Sta } \\
\text { co }\end{array}$ & $\begin{array}{l}\text { Murray } \\
\text { Grove }\end{array}$ & $\begin{array}{l}\text { SEKISUI } \\
\text { Heim } \\
\text { modular } \\
\text { house }\end{array}$ & $\begin{array}{l}\text { Space } \\
\text { box }\end{array}$ & $\begin{array}{l}\text { Carme } \\
1 \text { Place } \\
\text { (My } \\
\text { Micro } \\
\text { NY) }\end{array}$ & $\begin{array}{c}\text { Cale } \\
\text { doni } \\
\text { an }\end{array}$ \\
\hline $\begin{array}{c}\text { Usabilit } \\
\mathrm{y}\end{array}$ & 0 & () & 0 & 0 & 0 & O & 0 & 0 & 0 & 0 \\
\hline $\begin{array}{l}\text { Constru } \\
\text { ctability }\end{array}$ & () & 0 & (1) & () & () & 0 & 0 & 0 & 0 & 0 \\
\hline $\begin{array}{c}\text { Environ } \\
\text { mental } \\
\text { friendli } \\
\text { ness }\end{array}$ & $\mathrm{O}$ & 0 & 0 & () & 0 & O & 0 & 0 & 0 & ○ \\
\hline $\begin{array}{l}\text { Econo } \\
\text { mic } \\
\text { feasibili } \\
\text { ty }\end{array}$ & () & () & (1) & () & (1) & 0 & 0 & 0 & 0 & ( \\
\hline Design & 0 & (1) & 0 & 0 & (1) & (1) & (1) & (1) & 0 & 0 \\
\hline
\end{tabular}

\section{1) Usability}

The usability was relatively high in domestic and overseas cases. In the case of MUTO Cheongdam, the insulation performance was $8.7 \%$ higher than that of the previous apartment houses, and wet floor is used so that the legal lightweight impact sound is $58 \mathrm{db}$ or higher and heavyweight impact sound is $50 \mathrm{db}$ or higher, so the construction can also respond to noise between floors. Rental housing in Seodaemun-gu also showed low usability, and the outside insulation method is applied to rental housing for university students in Cheonyeon-dong, Seodaemun-gu. Absence of community space and balcony space were not considered. In the case of overseas space boxes, they are made of high-quality composites used for aircrafts and vessels, and thus, are effective for sound insulation and heat protection. In the case of Carmel Place, an elevation change was applied to ensure lighting and smooth ventilation. 


\section{2) Constructability}

The constructability is relatively low in domestic cases, and in the case of MUTO, the construction period was reduced by $50 \%$ and the variability of module shape is low. Internal core planning was not carried out, so there is a limitation in that the vertical moving line should be used through the outside stairs. The standardization of modules has not been carried out properly in most domestic cases, so there is difficulty in adding and in variability of unit modules. In overseas cases, it is possible to install an additional module or remove a module through the modular system according to the standardization, so constructability is relatively high. This appears to influence the modular architecture revitalization period. Also, the investment in unit module production facilities, studies on high-rise construction methods, and diversity and hybrid structure of module systems are required for increasing factory production.

3) Environmental Friendliness

Environmental friendliness was very high in all cases. In the case of SEKISUI Heim modular house, focus was placed on the improvement of habitability by introducing various environmentally friendly elements, including solar panels and insulation glass, and it was assembled at a certain height from the ground to ensure ventilation system and humidity control. Products almost finished through factory production were stacked on-site, ensuring very high reusability and recyclability, and the bearing wall method particularly ensures high insulation and air tightness. Noise and dust generation are also minimized on the construction site. Studies and technical developments in consideration of a climate change that is appearing due to recent environmental changes and changes in number of family members are necessary.

4) Economic Feasibility

In the case of MUTO, modular application is carried out uniformly in small-scale development, and the public dormitory in Gongneung-dong cannot be standardized due to its non-standard dimensions. The standardization of unit modules is also not carried out in other domestic cases, so construction has been carried out in various types of modules. In the case of Mini House in Guro-dong, it has been constructed using general architectural design methods, not large-volume factory production, which increases the design and construction costs. Since the size of the overseas modular architecture market is relatively large and revitalized, various overseas cases show that module development is being actively carried out. In order to improve the factory production rate, the standardization of modules should be considered.

5) Design

The cases show that there is a significant difference in the flexibility and design. This is because each country has different standards and procedures and there are also differences in 
cultural and environmental elements. According to analysis cases, modular architecture of less than 10 stories have structures that use the stacking method, and there are limitations in design diversity. In particular, domestic modular architecture cases show that unit modules are not standardized, so there is difficulty in their revitalization and R\&D. R\&D in consideration of the diversity and variability of modules and corresponding stability beyond uniform plane composition and stereotypical design of unit modules is necessary.

Domestic cases are limited to low-rise residential facilities of less than 11 stories, and the unit box method and penalizing method, except for where the in-fill method is used, have been used mainly for low-rise buildings. Various materials and colors were used for the diversity of units; however, similar form and structure were shown in the design and stacking methods. There are changes according to the internal and external position of core space for each case of modular architecture, and the functional role of the terrace and awning system for each unit has a significant influence on the uniformity of elevation.

\section{Unit Module Plan for the Design Diversity According to the Modular Architecture Construction Method}

The optimal specifications of unit module place emphasis on the movability. As shown in the investigation and analysis of conditions including the minimum road width $(3 \mathrm{~m})$, clearance $(4.2$ $\mathrm{m}$ ) and transportation equipment according to the law, the width of module less than $3.0 \mathrm{~m}$ and the length less than $6 \mathrm{~m}$ are appropriate by considering the overall length of vehicle. The height less than $3.1 \mathrm{~m}$ is reasonable by considering the height limit of pedestrian overpass and the height of transportation equipment. This figure considered the transportation size of low-bed trailer and 5-ton trucks, and the rational figure for transporting the module unit was set as $3.0(\mathrm{w}) \times 6.0(\mathrm{~d}) \times 3.1(\mathrm{~h})$. It was analyzed in this study that research on formative diversity considering economic feasibility and constructability are necessary, and it is judged that it would only be natural for environment-friendliness to be higher. As shown in the evaluation analysis table, it is evident in domestic cases that economic feasibility is low, and by proposing module plans considering this aspect, it will diversify the simple forms and be efficient in various aspects as well. Based on mass factor production by standardizing unit modules and limiting the restriction on plane changes, 10 limited cases were analyzed according to the evaluation standards, and two proposals were made for formative diversity. 


\subsection{Common Community Space and Core Planning}

The first method shows formative diversity according to common community space and core planning and it can present the diversity of overall repeated layer and intersecting layer in the shapes of $\neg,-$, and $ᄃ$ for the core space and common community space plans. By enhancing freedom of passages, various layering methods can appear through the joined unit module spaces. The outdoor area connected to outdoors for each module is wide, therefore making it possible to improve lighting and ventilation effects. The below figure shows that the passage and common community space according to unit modules are expanded based on the standardized figures. When applying to larger buildings, diversity of all levels become limited.
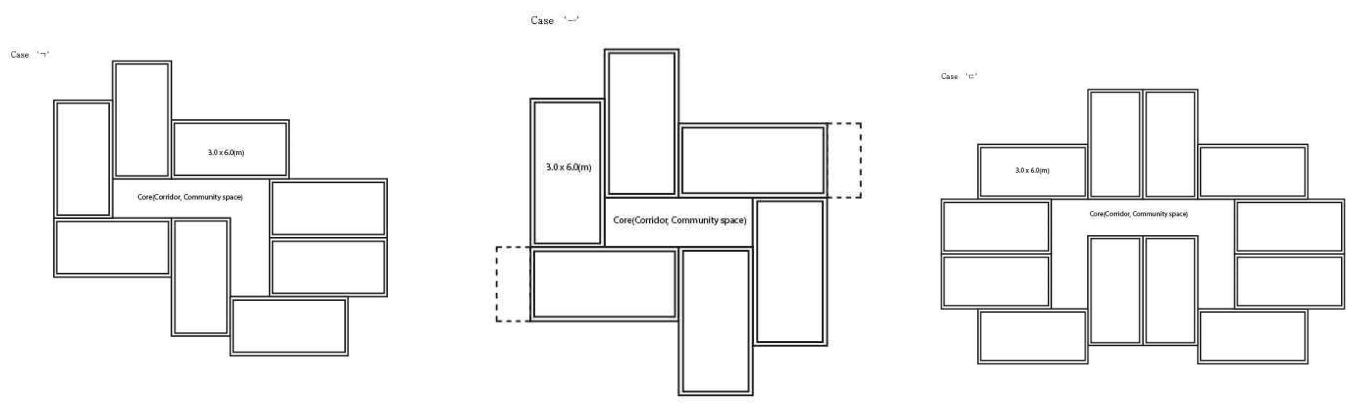

[Fig. 1] 'ᄀ, 一, ᄃ’ Public Community Spaces Forms

\subsection{Awning Structure and Terrace System Planning}

Second, we can consider the formative diversity according to the structure of shading and mining. It can potentially be applied to the existing modular construction and through unit modulization of the terrace or louver, economic feasibility and environmental friendliness can be improved. It is proposed that through the form or shading of the terrace on the side of unit module exposed to the outside or through assembly of structural systems or modularization, elevations can be diversified. As shown below, three methods were used to plan the shading or sunlight louver or terrace using 1 point, 2 point, and 3 point controls. Additional research is necessary in future because precise proposal and testing on louver materials and structural parts were not conducted. This study only proposes its possibility. The height was set as half of the height at $1.5 \mathrm{~m}$ and since the level of lighting and shading is different according to the height of the space, the louver and terrace figures appropriate for each level can be set through performance evaluations in the future. 

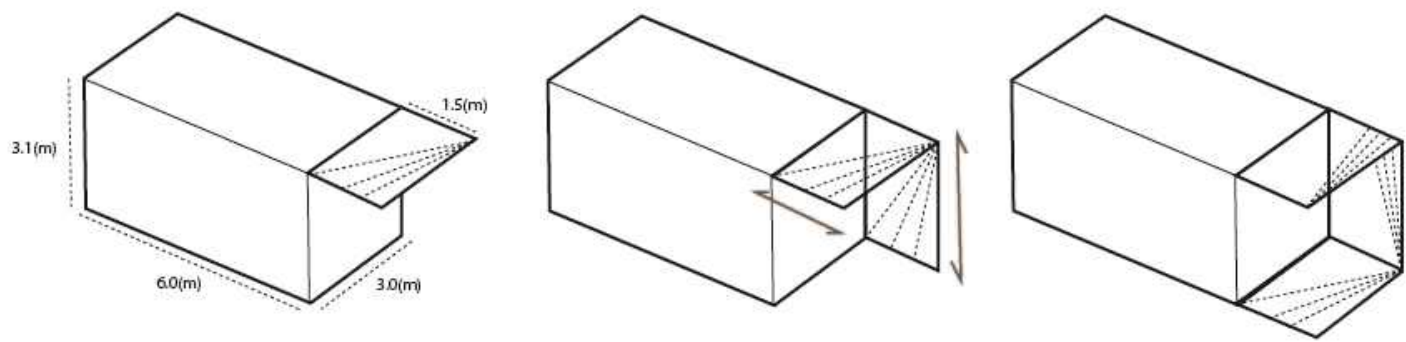

[Fig. 2] Unit Module of Awning Structure and Terrace System

\section{Conclusion}

The purpose of this study is to establish basic modular construction materials for the development of modular construction in Korea and for its formative diversity and promotion through comparative analysis on structure types through domestic and foreign cases.

Case-study methods on the concept of modular construction and particular unit modular systems were examined through theoretical studies. Five domestic and five foreign residential facility modular construction cases were selected to study structure type of module and features of domestic and foreign cases, while examining usability, constructability, environment-friendliness, economic feasibility, and design through comparative analyses. It was found that constructability and economic-feasibility were high for cases other than domestic cases, while it was found to be superior in all cases for the environment-friendly aspect. It was found to be relatively low for flexibility and design, and the composition of unit modules showed uniform and simple lanes. Based on the case-studies, it was judged that formative diversity considering economic feasibility and constructability is necessary and it was possible for environment-friendliness to be high as well. Two methods are proposed for formative diversity focusing on the analyzed cases. First is the formative diversity for common community spaces and core planning. In the second method, diversification methods using shading system unit modulization of the terrace or unit module could be considered, and by using a hybrid structure for taller buildings, it is possible to make tall-building structures considering economic stability. As it is necessary to conduct research and construct a sustainable and environment-friendly system, core spatial planning and unit modules were proposed as methods to grant formative diversity of modular construction. The size of the unit 
module was set at $3.0(\mathrm{w}) \times 6.0(\mathrm{~d}) \times 3.1(\mathrm{~h})$, considering the means of transportation and the space and common community spatial planning was made in the shape of $\neg$, - , and ᄃ, while giving diversity in volume for the overall stacked layers and intersecting layers. In addition, for the side of unit module exposed to the outside, plans to diversify the elevations can be considered through the shape of terrace and structure system that provides lighting and shading functions, or through modulized assembly. Based on this, it is expected to be used as a basic material for future studies on applying unit module and stack method diversity in modular construction. In future studies, analyses should be made according to the types and methods of various facilities, testing on diversity of unit modules, and eco-friendly performance research should be carried out for the efficiency of the proposed module construction.

\section{References}

[1] J. H. Kim, I. M. Park, The Practical Application of Modular Construction for Residential Facilities, Journal of the Korean Housing Association, (2013), Vol.24, No.3, pp.19-26, DOI: 10.6107/JKHA.2013.24.3.019

[2] D. H. Lee, J. H. Ock, A Study on the Application of the In-Fill Construction Method to High-Rise Unit Modular Buildings, Journal of the Architectural Institute of Korea Structure \& Construction, (2014), Vol.30, No.3, pp.105-114, UCI: G704-B00167.2014.30.3.006

[3] Y. A. Mun, M. K. Kim, M. J. Park, Domestic and Foreign Case Studies for the Improvement of Unit Modular Housing, Journal of the Architectural Institute of Korea, (2013), Vol.29, No.10, pp.65-73, UCI: G704-A00167.2013.29.10.005

[4] J. Y. Kim, J. K. Lee, A Basic Study on the Application of Modular Construction - Focused on the Analysis of Case Study, Journal of the Korean Housing Association, (2014), Vol.25, No.4, pp.39-46, DOI: 10.6107/JKHA.2014.25.4.039

[5] H. H. Kang, C. S. Lee, Factors comparison for activating domestic Modular Construction, Recent Advances in Korea Institute of Construction Engineering and Management, Proceedings of the 10th National university student conference publication, (2015), November 7; Seoul, Korea.

[6] J. Y. Kim, A Study On The Type Analysis Of The Modular Architecture Based On Container, Department of Architecture, Graduate School of Konkuk University, Master's thesis, (2015)

[7] Y. H. Jeon, A Study On The Modular Construction Of Low-Rise Multi-Family Housing Design, Dept. of Architecture, Graduate School of Gachon University, Master's thesis, (2014)

[8] Y. H. Jun, G. C. Lee, Y. Lee, An Unit Module Plan of Cross Stacking Method for Design Diversity, Journal of the Architectural Institute of Korea Structure \& Construction, (2015), Vol.31, No.5, pp.77-85, DOI: 10.5659/JAIK_SC.2015.31.5.77

[9] J. S. Lee, A Study on The Prototype for Vitalizing Modular Housing, Hongik University, Master's thesis, (2014) 
[10] S. P. Jung, A Study on The Expandability of Modular Buildings, Yeungnam University, Master's thesis, (2017)

[11] W. C. Wang, S. H. Lim, A Study on the Space Expansion of Temporary Housing to Utilize Modular mock-up, Journal of the Architectural Institute of Korea, (2014), Vol.30, No.4, pp.103-111, UCI: G704-A00167.2014.30.4.014

[12] https://blog.hmgjournal.com/Group-Story/hec-modular-architecture.blg/, Sept 10 (2018)

[13] http://www.jutek.kr/user/selectBbsColumn.do?BBS_NUM=212\&COD03_CODE=c0318, Sept 25 (2018)

[14] https://www.dezeen.com/2016/11/18/worlds-tallest-modular-prefabricated-apartment-tower-shop-architectsbrooklyn-new-york/, Sept 10 (2018)

[15] https://www.architectmagazine.com/project-gallery/the-stack_o, Sept 20 (2018)

[16] https://inhabitat.com/nyc/prefabricated-broadway-stack-apartments-break-ground-in-manhattan/, Sept 21 (2018)

[17] http://graftlab.com/portfolio_page/paragon-apartments/, Sept 1 (2018)

[18] http://www.cartwrightpickard.com/projects/offsite/murray-grove/, Sept 1 (2018)

[19] https://casalibrary.com/2016/09/05/berlin-paragon-apartments-by-graft-berlin/, Sept 5 (2018) 